\title{
Global Innovation in Foreign Subsidiaries: The Impact of Entrepreneurial Orientation and Corporate Networks
}

\author{
Sidney Costa $^{\dagger}$ \\ FEA/USP-RP \\ Felipe Mendes Borini ${ }^{\Omega}$ \\ PMDGI
}

\begin{abstract}
The article aims to show the differentiated moderating role of integration between the headquarters and subsidiary companies to explain the potential of local innovations becoming global innovations. Throughout the framework and hypotheses, we propose two global innovation development processes. In order to test them, we analyzed a sample of 172 subsidiaries from the structural equations technique to test the hypotheses and multiple-groups comparison in order to evaluate the moderating effect of subsidiaries embeddedness. The results confirm the adherence of a presented process: entrepreneurial orientation is associated with local innovation when moderated by embeddedness. In turn, this local innovation has great potential to become a global innovation. Another result diverged from the one presented in the hypotheses, but it has an important contribution. The result shows that the entrepreneurial orientation is associated with the inclusion of the subsidiary in the network, which has the potential of developing global innovation, but to do so it would have to be a radical or disruptive innovation.
\end{abstract}

Keywords: Innovation global; Enterprise network; Embeddedness; Entrepreneurial orientation; Subsidiaries.

\section{INTRODUCTION}

Within the theme of Multinational Corporations (MNCs) management research relating to the transfer of knowledge and innovation date back to the heart of corporate strategy since the advent of transnational strategy (BARTLETT; GHOSHAL, 1989, 1999). Several factors are listed to explain the motivators and barriers in order to transfer knowledge and innovation (MICHAILOVA; MUSTAFFA, 2012). The last decade, reflecting the focus of international business studies guided by the theory of networks, has highlighted the role of subsidiaries embeddedness in the host country networks as a determining factor to explain the generation of knowledge and innovation in the subsidiaries which then can be transferred globally to MNC (ANDERSSON, 2003; ANDERSSON; BJÖRKMAN; FORSGREN, 2005; ANDERSSON; FORSGREN; HOLM, 2002; CIABUSCHI; HOLM; MARTÍN MARTÍN, 2014; DELLESTRAND, 2011; GNYAWALI; HATFIELD, 2007; HEIDENREICH et al., 2012).

In parallel with the growing importance of networks to explain the generation of global innovation, studies in management of multinational corporations were marked by the evolutionary perspective of subsidiaries (BIRKINSHAW，1997，2001; BIRKINSHAW;HOOD;JONSSON,

Corresponding author: ${ }^{\dagger}$ Faculdade de Economia, Administração e Contabilidade.

E-mail: sidneycosta@usp.br

$\Omega$ PMDGI.

E-mail: fborini@espm.br

Received: $12 / 09 / 2015$. Revised: 03/04/2016.

Accepted: 04/01/2016.

Published Online: 02/01/2017. 
1998a). Birkinshaw (1997), researching the entrepreneurism of subsidiaries, paved the way for a series of studies investigating the role of entrepreneurial orientation and subsidiaries self-initiative, that may have the potential to become a global innovation (SCHMID; DZEDEK; LEHRER, 2014).

These two aspects reported above, the inclusion of subsidiaries in the network and the entrepreneurial orientation raise an important question in relation to the dilemma of the geographical scope of innovation. The matter of debate in the literature is what causes a local innovation of the subsidiary resulting from the entrepreneurial orientation and insertion into a global innovation network (RUGMAN; VERBEKE, 2001). Studies by MEYER, MUDAMBI and NARULA ( 2011) and by NARULA, (2014) strongly emphasize the need for integration between the headquarters and subsidiaries (NOHRIA; GHOSHAL, 1997) as a key element so that local innovation can become a global innovation. This is because embeddedness, understood as the strong alignment between subsidiary and headquarters, would allow that the innovation of the subsidiary were more easily recognized and used by the headquarters and other corporate units (BIRKINSHAW et al., 1998a; FROST; BIRKINSHAW; ENSIGN, 2002).

However, this solution is not simple. The entrepreneurial orientation preceded by a strong embeddedness with the headquarters can reduce the capacity that local innovation to differ from other innovations of the MNC (BOUQUET; BIRKINSHAW, 2008), simply by restricting the choices of the subsidiary to the overall strategy of the MNC. On the other hand, a strong embeddedness between subsidiary and headquarters appears to decrease chances of the subsidiary having a strong presence in the local network in order to find an unorthodox MNC innovation (ANDERSSON et al., 2005).

Thus, for a local innovation to become global, albeit embeddedness between headquarters and subsidiaries companies (NOHRIA; GHOSHAL, 1997) appears to play a key role, the remaining question in the literature is: what is the role played by embeddedness? In this article, we argue that embeddedness plays a moderating role in the development of the global innovation process. In other words, the article shows the differentiated moderating role of embeddedness between headquarters and subsidiaries companies to explain the potential of local innovation becoming global innovations.

The contribution presented in relation to the established literature (ACHCAOUCAOU; MIRAVITLLES; LEÓN-DARDER, 2014; FIGUEIREDO, 2011; FIGUEIREDO; BRITO, 2011; MEYER et al., 2011; NARULA, 2014) is that in our view, albeit embeddedness playing a moderating role, this moderation is different as the development process of local innovation that can become global. Guided by the perspective of networking and entrepreneurial orientation of subsidiaries, we advocate two different processes of global innovation development. In each innovation process, embeddedness plays an essential role, despite embeddedness moderation occurring at different times.

Thus, the structure of the article is presented as follows: the theoretical framework presents the key aspects of global innovation and, based on the context of entrepreneurial orientation and business networks presents both global innovation development processes and the differentiated moderating role of embeddedness. The methodology presents the survey conducted with foreign multinational subsidiaries in Brazil, the constructs and the prerequisites for structural equation modeling applied. The results test the hypotheses, followed by discussion and implications of the findings for the subsidiary management literature.

\section{THEORETICAL FRAMEWORK}

Innovation can be understood as the implementation of a product (good or service) or a new or significantly improved process, and their achievement takes place only after the product is offered to the market, or after the implementation of the process (TIDD; BESSANT, 
BBR

14,4

2015). The two most researched types of innovations are innovations in product and process (HAMEL; BREEN, 2007). In this sense, this article focuses on innovations in product and process. As for the source of innovation, it can originate in two ways (CHESBROUGH, 2006): (i) within the company, mainly based on internal R\&D and other organizational functions and (ii) from sources outside the company, based on partnerships and collaborative networks. The author points out that the classical and predominant perspective of innovative development was - and it continues to be — the position of the company specializing in developing their innovations in solitary, solely from its research centers. However, this model has encountered barriers concerning the limitation of ideas and the increased cost of developing innovations, which now have their development cycles ever shorter. In opposition to this model, companies can use not only internally developed ideas as well as the ones externally sourced, such as: suppliers, customers and universities. In summary, open innovation is based on the search for competitive advantages from the intensification of relationships with external partners (CHESBROUGH, 2006). So in this article, when we talk about innovation in products and processes, we understand the possibility of this innovation being developed in both, closed and open manners. The fact of the product innovation process having the possibility of being closed and open, dialogues with the dominant paradigm of current studies on MNCs strategy. If, on the one hand, the transactional paradigm advocates for closed innovation (BARTLETT; GHOSHAL, 1989), the metanational paradigm (DOZ; SANTOS; WILLIAMSON, 2001) clearly advocates the open model. Thus, multinational companies, through its subsidiaries, strive to acquire and utilize the innovation developed in different parts of the world. Within a transnational strategic perspective (BARTLETT; GHOSHAL, 1989) and metanational (DOZ et al., 2001), can and should be transferred to the entire corporation as a way to configure the a competitive differential of the multinational company before other national ones. Thus, innovation resulting from subsidiaries can be an important source of competitive advantage, provided it is able to be used in other business units, i.e., innovation needs to configure a non-local capacity (RUGMAN; VERBEKE, 2001).

This perspective of the transfer of knowledge and innovation is the source of much discussion on the subsidiaries management literature in the last decade (MICHAILOVA; MUSTAFFA, 2012).

Studies show the association between local and global innovations (BIRKINSHAW, 2001; BIRKINSHAW et al., 1998a; BIRKINSHAW;HOOD;YOUNG, 2005; FROST et al., 2002), including foreign subsidiaries located in Brazil (BORINI; OLIVEIRA JUNIOR; SILVEIRA; CONCER, 2012; COSTA; BORINI; AMATUCCI, 2013; OLIVEIRA JR; BOEHE; BORINI, 2009). Thus, the debate in the literature resides in the local innovation development process to become a global innovation (CIABUSCHI; DELLESTRAND; HOLM, 2012; DELLESTRAND, 2011; MEYER et al., 2011; NARULA, 2014). The dilemma is on how to perform an innovation that enables the subsidiary to differentiate within the internal competition of the MNC (BOUQUET; BIRKINSHAW, 2008; MUDAMBI; PEDERSEN; ANDERSSON, 2014), but that is, concurrently an innovation capable of being moved and used internally (CANTWELL; MUDAMBI, 2005; FROST et al., 2002).

Three concepts of the literature on subsidiaries management are heavily involved in this debate. First, the entrepreneurial orientation of the subsidiary (BIRKINSHAW, 1997; BIRKINSHAW et al., 1998a; SCHMID et al., 2014) which assumes the support of the MNC so that the affiliate can commit to risky and innovative decisions on their own. The entrepreneurial orientation would be essential to create innovation in subsidiaries (KEUPP; GASSMANN, 2009; SCOTT; GIBBONS; COUGHLAN, 2010; WILLIAMS, 2009). Second, the insertion into the external network in which 
the literature (ANDERSSON et al., 2002; DELLESTRAND, 2011; FIGUEIREDO; BRITO, 2011; NELL; AMBOS; SCHLEGELMILCH, 2011) claims that the inclusion of the subsidiary in the host country network allows access to differentiated business standards arising from the competitive environment, which in turn, has the power to stimulate subsidiary innovations which could not be developed by the headquarters. Finally, the embeddedness issue between headquarters and subsidiary as a central aspect to align innovation of subsidiaries with the corporate strategy of the MNC (ACHCAOUCAOU et al., 2014; CIABUSCHI et al., 2014; FIGUEIREDO, 2011; MEYER et al., 2011). Our aim, in the section of hypotheses that follows, is to articulate these three concepts in order to show two different processes of development of global innovation in subsidiaries, where embeddedness plays a central moderating role, but in different stages of the innovation process.

\section{HYPOTHESES}

The two global innovation development processes we advocate have the entrepreneurial orientation as a basis for generation of innovation. (BIRKINSHAW, 1997; BIRKINSHAW et al., 1998a). In the first process of development of innovation, we believe that the entrepreneurial orientation leads to local innovation of the subsidiary and this can become global innovation. However, for this to happen, we advocate that the creation of local innovation-based entrepreneurial orientation has to be moderated by a strong embeddedness of the subsidiary with the headquarters.

In most of the literature, the initiatives are seen as a source of competitive power within the MNC (BOUQUET; BIRKINSHAW, 2008; MUDAMBI et al., 2014) through the possibility of creating resources, capabilities and global-mandate gain (Schmid et al., 2014). However, when considering the entrepreneurial orientation an autonomous activity of the subsidiary, many studies advocate that developing their own initiatives without the embeddedness with the headquarters can be risky for the detachment of the subsidiary (DIMITRATOS, LIOUKA; ROSS; YOUNG, 2009). Therefore, it is essential that the entrepreneurial orientation is aligned with the strategies of the MNC, i.e., the embeddedness would allow the subsidiary to develop local innovations that have the possibility of being recognized and reapplied in other units of the company (BIRKINSHAW et al., 1998a; BIRKINSHAW et al., 2005).

In this case it is likely that local innovation has an internal focus to meet the requirements established by the corporation (BIRKINSHAW, 1997; BIRKINSHAW;RIDDERSTRÅLE, 1999; DELANY, 2000; SCHMID et al., 2014; WILLIAMS, 2009) and thus create the possibility of it becoming a global innovation. Thus, the first global innovation development process of the subsidiaries can be described by the hypotheses below.

H1a: Entrepreneurial orientation of the subsidiary, when moderated by embeddedness between headquarters and subsidiaries, is positively associated with local innovation.

H1b: Local subsidiary innovation is positively associated with global subsidiary innovation.

On the other hand, the innovations of the subsidiary do not always meet the internal demand of the MNC, i.e., it can be a market initiative to solve a specific problem of the external competitive market demand (BIRKINSHAW, 1997; BORINI; FLEURY; FLEURY; OLIVEIRA JR, 2009; DELANY, 2000; SCHMID et al., 2014). This entails a second course in the development of the global innovation process. The entrepreneurial orientation, instead of stimulating as a focus the internal market in the MNC (BOUQUET; BIRKINSHAW, 2008), stimulates initiatives further linked to the external market, this leads to the subsidiary having greater embeddedness in the host country's external network (ANDERSSON et al., 
BBR

2002; FORSGREN, 2008). Thus, the insertion into the external network has a mediating role for the creation of the local subsidiary innovation.

The major problem of this innovation process is that many of the innovations resulting from this path tend to stay in their own subsidiary, as they solve a local problem, but they are not aligned with the strategy of the MNC. They tend to be specific local market innovations, difficult to be transferred (RUGMAN; VERBEKE, 2001). However, some not only have the potential to become global, as indeed do become a global innovation (CANTWELL; MUDAMBI, 2005; FROST et al., 2002; NARULA, 2014). In this case, the literature (ACHCAOUCAOU et al., 2014; ANDERSSON, 2003; FIGUEIREDO, 2011; MEYER et al., 2011; NARULA, 2014) suggests the role of embeddedness between headquarters and subsidiary to align local with global innovation. However, we see that embeddedness moderation should take place after the local innovation had already been developed, in other words, in a second moment, different from the first innovation development process described above. Thus, the argument leads us to the following hypotheses:

H2a: Entrepreneurial orientation is positively associated with the insertion of the subsidiaries into the external network of the host country.

$H 2 b$ : The insertion of the subsidiaries into the external network of the host country is positively associated with local subsidiary of innovation.

H2c: Local innovation subsidiary when moderated by the embeddedness between headquarters and subsidiaries is positively associated with global subsidiary innovation.

Figure 1 summarizes the two global innovation processes presented in the cases. Our goal is to show that the relationship between the entrepreneurial orientation and embeddedness is essential for local innovation becoming global innovation. However, the integration has a moderating effect at different times, i.e., depending on the procedural innovation path. If innovation does not require the insertion into the external network, embeddedness exerts its moderating role in aligning the entrepreneurial orientation of the subsidiary and the development of local innovations linked to the overall strategy of the MNC. On the other hand, if the innovation originates from an entrepreneurial process, which includes the insertion into external networks, then the embeddedness exerts a moderating role, but not in the development of local innovation, but the alignment of the local innovation with global innovation, in order to convince the headquarters that the local initiative has global potential. Thus, what this article proposes is a different perspective of moderation of embeddedness depending on the entrepreneur's subsidiary process.

\section{METHODOLOGY}

Empirical data were collected from a survey with foreign multinationals in Brazil applied online with phone monitoring. The respondent was the chief executive of the subsidiary or any board member nominated by the executive. The survey returned a total of one hundred and eighty one questionnaires, nine of which, were excluded for incomplete or incorrect filling. Thus, the research sample consists in one hundred seventy-two companies, a percentage of $17 \%$ responses. For data analysis, we used the statistical modeling technique for structural equation modeling (SEM), in which we performed several tests to verify the robustness and reliability of the data.

All variables are measured on a Likert scale of five points, with an extreme value "1" indicating strongly disagree and " 5 " indicating totally agree. Due to the impossibility of direct measurement, the latent construct is represented by one or more latent variables or indicators, that are constituted in the observable variables (BYRNE, 2009; HAIR et al., 2009; KLINE, 2005). The model presented in this study (Figure 1) is characterized as reflective, since the direction of causality runs from the construct to its indicators. In other 


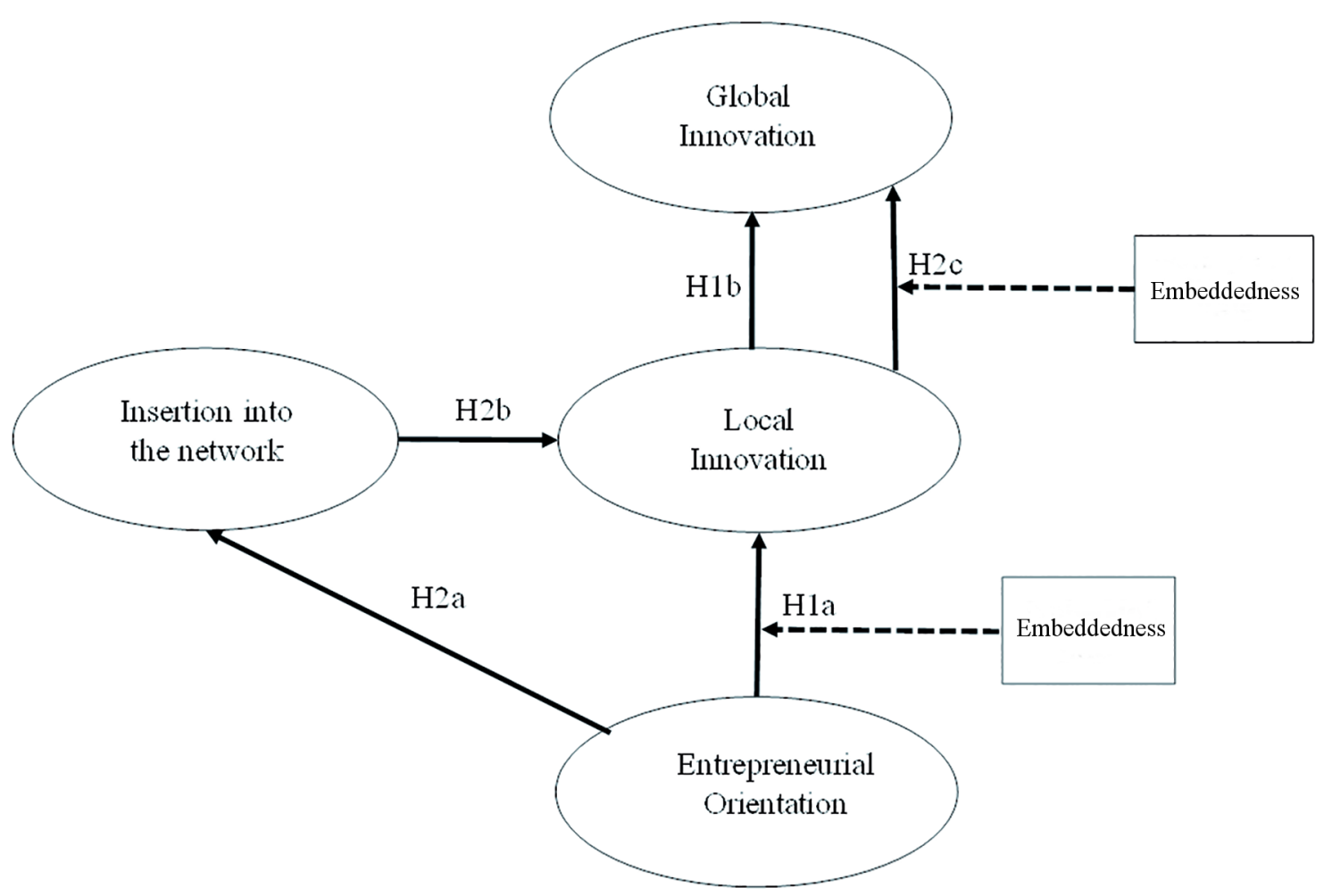

Figure 1. The development process of the global innovation in subsidiaries Source: developed by the authors

words, in this type of model, changes in the construct cause changes in items (JARVIS; MACKENZIE; PODSAKOFF, 2003).

We propose five constructs: local innovation, global innovation, business networks, entrepreneurial orientation and integration.

The construct referring to the global innovation was adapted from Birkinshaw, Hood and Jonsson (1998b); Frost et al. (2002). The construct is formed by the following variables: v6) the subsidiary has permission headquarter to perform innovation projects; v7) develops products that today are sold by other subsidiaries; v8) developed organizational processes that are now adopted in other subsidiaries ev9) develops organizational products/processes in partnership with suppliers and that are now adopted in other subsidiaries.

The construct local innovation (BIRKINSHAW; HOOD; JONSSON, 1998) is formed by: v10) change in the design of products/services offered; v11) create new products/services; v12) entering new markets inside the country; v13) changing production processes and v14) developing new suppliers and partners.

The construct business networks was adapted from studies by Doz, Santos and Wililiansons (2001); Anderson, Forsgreen and Holm (2002) and Lakshman and Parente (2008) and is formed by the following variables: v1) Our subsidiary has extensive experience with strategic partnerships and alliances with our suppliers; v2) Our subsidiary has a long history in the preparation and development of partnerships in the past; v3) Our subsidiary has as common practice the development of partnerships; v4) Our subsidiary is always looking for opportunities to make new strategic alliances and partnerships and v5) Our subsidiary considers strategic partnerships and alliances matters of vital important to our business.

The entrepreneurial orientation construct (BIRKINSHAW, 1997; BIRKINSHAW; HOOD, 1998) is formed by the variable: v15) support for risk decisions of subsidiary executives; v16) support for entrepreneurial activities and v17) strong confidence of the headquarters in its subsidiary. 
BBR

14,4

Embeddedness is the moderating variable. It is a dummy variable based on Birkinshaw, Hood and Jonsson (1998) measuring the high or low embeddedness of the subsidiary with the headquarters in terms of alignment asked in terms of information exchange, knowledge and work between the parties. High embeddedness (dummy value 1) occurs when there is a high exchange of information, knowledge and work between headquarters and subsidiaries, when the value of the dummy is lowered it is zero.

\section{ASSUMPTIONS AND MODEL FIT INDICES}

Table 1 presents the Pearson correlation coefficient and the Variance Inflation Factor (VIF) test, whose correlation coefficients have positive values lower than 0.85 (KLINE, 2005 ) and VIF test meets the parameter recommended in the literature: VIF $<5$ (Marôco, 2010).

Table 1. VIF correlation and test

\begin{tabular}{lccccccc}
\hline & VIF & Mean & Deviation & I & II & III & IV \\
\hline I - Insertion into the network & 1.15 & 3.80 & 0.69 & 1 & & & \\
II - Local Innovation & 1.06 & 3.70 & 0.78 & $0.23^{* *}$ & 1 & & \\
III - Global Innovation & 1.15 & 2.90 & 0.77 & $0.41^{* *}$ & $0.24^{* *}$ & 1 & \\
IV - Entrepreneurial Orientation & 1.16 & 4.00 & 0.64 & $0.37^{* *}$ & $0.24^{* *}$ & $0.23^{* *}$ & 1 \\
\hline
\end{tabular}

${ }^{* *} \mathrm{P}<0.01$ and ${ }^{*} \mathrm{P}<0.05$ Source: the authors

Given the fact that the dependent and independent variables are drawn from a questionnaire, the issue of Common Method Bias (CMB) may occur. Accordingly, we performed Harman's factor analysis (PODSAKOFF; ORGAN, 1986), which presented a common variance of $31.90 \%(<50 \%)$ and therefore satisfactory.

In addition to the linearity and multicolinearity test and $\mathrm{CMB}$ detection, data were also submitted to the normality test whose kurtosis presented the value of $0.37(<|2|)$ while the symmetry presented the value of $0.83(<|1|)$ and met the statistical requirements suggested by Kline (2005). As for the sample used in this study $(n=172)$, Hair et al. (2009) adds that for the use of the structural equation technique, samples between 100 and 200 are satisfactory, in addition, many studies have been developed with similar samples, e.g.: $\mathrm{n}=$ 169 by Foss, Laursen and Pedersen (2011), $n=104$ by Chang, Cheng and Wu (2012) and $n$ $=158$ by Li, Wang, Huang by Bai (2013).

With these tests accomplished, two other validations are necessary for the model: convergent validity and discriminant validity. For the convergent validity what is suggested as ideal (HAIR et al., 2009): Composite Reliability (CR > 0.7) and Variance Extracted $(\mathrm{AVE}>0,5)$. After obtaining the standardized regression coefficients, we began calculating the CR and the AVE. From the analysis of the loads of each indicator (v1, v2, v3...v16) we opted for the removal of the lower load indicator, since it is a good practice to access individual fittings of each construct to determine which item is the weakest and then remove it from the analysis (HOOPER; COUGHLAN; MULLEN, 2009). Once the removal was done, the model was re-calculated and thus new standardized regression coefficients were generated, which were again used to calculate the CR and the AVE until the suggested indices were satisfied as shown in Table 3.

Once the convergent validity was verified, it is also necessary to verify the discriminant validity which consists of measuring the difference between constructs. To perform this measurement, we used the method of shared variances (Table 2), suggested method by Fornell and Larcker (1981). It appears that the constructs meet the specificities of the proposed method by Fornell and Larcker (1981), since the $\mathrm{R}^{2}$ are lower than the AVE values (in bold), demonstrating that the discriminant validity is accepted for all constructs. 
Table 2. Discriminant Validity: Criterion by Fornell and Lacker (1981)

\begin{tabular}{lcccc}
\hline & I & II & III & IV \\
\hline I - Insertion into the network & 0.74 & & & \\
II - Local Innovation & 0.02 & 0.62 & & \\
III- Global Innovation & 0.03 & 0.05 & 0.51 & 0.60 \\
IV - Entrepreneurial Orientation & 0.01 & 0.01 & 0.01 & \\
SOURCE: the authors & & &
\end{tabular}

Finally, the resulting structural model presented suitable fitting indexes to the complexity of the model. Namely: $\mathrm{X}^{2} / \mathrm{df}=1.64 ; \mathrm{CFI}=0.95$; GFI $=0.90 ;$ AGFI $=0.84$; TLI $=0.93$; $\mathrm{RNI}=0.84$ and RMSEA $=0.04$. The results meet the references suggested by Hair Jr. et al. (2009) and Maroco (2010), where: $\mathrm{X}^{2} / \mathrm{df}<2.0$; CFI > 0.90; GFI > 0.90; AGFI > 0.90; TLI $>0.90 ; \mathrm{RNI}=0.90$ and RMSEA $<0.08$. Although the AGFI nad RNI measures presented values below the recommended indexes, we emphasize the recommendation by Hair Jr. et al. (2009) who guide us not to use the rules of measurement (Goodnes-of-fit $\geq 0.90$ ) as an absolute rule, because other factors such as sample size and the estimators can influence in the result of the model. Moreover, it is necessary to consider the reasonableness of the research and the contribution to the field of study (Mulaik et al., 1989). Hair Jr. et al. (2009) understand that no single magic value for the fit indices separates the good models from the bad ones, so that the goodness of fit depends considerably on the complexity of the model, so that simpler models require stricter standards than more complex models. In this sense, we emphasize that the tested model in this research includes four interconnected constructs, which sometimes behave as independent variables, or as dependent variables, with two mediating and two moderating variables, which characterizes a complex model (CHANG; WITTELOOSTUIJIN e EDEN, 2010). Furthermore, this research address three emerging themes in international business which should be better understood, in particular, in contexts of developing nations where there have been few studies shedding light on the subject using the perception of multinationals' senior executives.

Table 3 shows structural models containing the measures for the constructs and the component variables of the model. In this Table, it is possible to verify the relationship between the variables of the model, as well as their respective weights on each construct. The high values of standard loads $(\lambda)$ constituting the constructs suggest the importance of these variables for model prediction. According to Hair Jr. et al (2009), also suggest a good model fit since the commonalities are high (above 0.6).

In order to increase the reliability of the model advocated in this research, we followed Kline's (2010) recommendation, who suggests conducting a comparison between the advocated model and another equivalent alternative model. The importance of this test is to decrease the research bias by not ignoring other explanations for the data from another model. The results showed that the model chosen by the research presents fitting indexes higher than the alternative model, suggesting that it is in fact the most appropriate for the research.

\section{MEDIATION ANALYSIS}

The evaluation of the factors that lead to global innovation in subsidiaries has two mediating elements: insertion into the network and local innovations. For a variable to be considered a mediator, it is necessary that it meets the following conditions (BARON; KENNY, 1986): (i) variations in the independent variable imply significant variations on the mediating variable (A); (ii) variations in the mediating variable imply significant variation in the dependent variable (B); (iii) when the A and B paths are controlled, a previously significant relationship between the independent variable and the dependent is no longer significant. 
BBR

14,4

425

Table 3. Measures

\begin{tabular}{|c|c|c|c|c|c|c|c|}
\hline \multicolumn{8}{|c|}{ Foreign Subsidiary $(\mathrm{n}=172$ or $17 \%)$} \\
\hline Construct & Variables & $\lambda^{\mathrm{a}}$ & t Value & $\mathrm{R}^{2}$ & $\alpha^{\mathrm{b}}$ & $\mathrm{CC}$ & AVE \\
\hline \multirow{3}{*}{ Insertion into the network } & V3 & 0.89 & 1.00 & 0.78 & 0.89 & 0.90 & 0.74 \\
\hline & V4 & 0.91 & 15.18 & 0.83 & & & \\
\hline & V5 & 0.79 & 12.72 & 0.62 & & & \\
\hline \multirow{3}{*}{ Global Innovation } & V6 & 0.66 & 7.00 & 0.44 & 0.75 & 0.76 & 0.51 \\
\hline & V7 & 0.68 & 7.10 & 0.46 & & & \\
\hline & V8 & 0.79 & 1.00 & 0.62 & & & \\
\hline \multirow{3}{*}{ Local Innovation } & V10 & 0.92 & 1.00 & 0.85 & 0.82 & 0.83 & 0.62 \\
\hline & V11 & 0.78 & 9.62 & 0.61 & & & \\
\hline & V13 & 0.64 & 8.17 & 0.41 & & & \\
\hline \multirow{3}{*}{ Entrepreneurial Orientation } & V14 & 0.72 & 1.00 & 0.52 & 0.80 & 0.81 & 0.60 \\
\hline & V15 & 0.93 & 8.70 & 0.87 & & & \\
\hline & & 0.63 & 7.80 & 0.39 & & & \\
\hline
\end{tabular}

Note: (a) Standardized Iten;(b) Cronbach's alpha. SOURCE: the authors

Mediation is accomplished by a third variable by which the independent variable influences the dependent variable (BARON; KENNY, 1986); in other words, the presence of the mediator variable, the relationship between the independent variable and the dependent variable changes. These conditions are tested for the supposed mediating constructs present in the proposed model, evaluating the loads and their significance for the model with mediation and without the mediating variable. In this research mediators constructs are: : insertion into the network and local innovations.

\section{MODERATION ANALYSIS}

Moderating effects occur when a moderating variable influences the level of the direct effects between an independent variable and a dependent variable (HENSELER;FASSOTT, 2010). In other words, a moderating variable affects the direction or strength of the relationship between two other variables, the moderating variable may be qualitative or quantitative, and many of the variables are discrete and nominal (BARON; KENNY, 1986; SAUER; DICK, 1993). When one or both variables that are interacting are discrete, one can use the multiple-groups approach, with the interaction effects revealing themselves when the same model is applied to different sets of data, though related (RIGDON; SCHUMACKER; WOTHKE, 1998). When the moderating variable is categorical, the clustering of variables without further refinements can be used. However, when a continuous numeric variable is used as a clustering variable, it is necessary, first of all, to transform it into a categorical variable dichotomizing it in two values.

This procedure was performed in the variable used in this study: Embeddedness variable (Figure 1). The variable "embeddedness" is a dummy one, where 0 represents a low embeddedness and 1 represents a high one.

These indicators are different and, therefore, are called multiple-groups. The variable embeddedness refers to the alignment between subsidiaries and headquarters. Thus, the sample was divided into two parts and we proceeded to a significance test to detect possible differences between the samples from the multiple-group comparison performed on the IBM Amos software in conjunction with Microsoft Excel. 


\section{RESULTS}

Table 4 shows the significance tests of the hypotheses without the moderation of embeddedness, and the weight of each relationship in the structural model. In other words, the hypotheses can be analyzed $\mathrm{H} 1 \mathrm{~b}, \mathrm{H} 2 \mathrm{a}$ and $\mathrm{H} 2 \mathrm{~b}$.

In turn, Table 5 shows possible relationships in proposed model without the moderation of embeddedness, but that have not been defended in the hypotheses. The test must be done, for despite us not having advocated on these relationships, we cannot leave them unclear. What is expected is that these associations are not significant, but if any is significant it is appropriate to have knowledge in order to reflect on the fact of not having advocated these associations

To accept the hypothesis (Table 4) or associations not proposed (table 5), the Critical Ratio (C.R.) must be superior to 1.96 for a significance at the 0.05 level and above 2.58 for a significance at the 0.01 level. Given the statistical indexes, the H1b, H2a, H2b hypotheses were supported. The hypothesis $\mathrm{H} 1 \mathrm{~b}$ expresses the relationship between the development of local innovation and global innovations. This hypothesis was supported $(\mathrm{p}<0.05)$ and presented a 0.15 impact. $\mathrm{H} 2 \mathrm{a}$ is supported $(\mathrm{p}<0.001)$ presenting the greatest impact on the model 0.47 , showing that entrepreneurial orientation is associated with the insertion into the network. In turn, insertion into the network shows positive association with local innovation, supporting $\mathrm{H} 2 \mathrm{~b}(\mathrm{p}<0.05)$ and presenting an impact of 0.31 .

Regarding the associations not proposed - although two of them not presenting significance -, an association was significant $(p<0,01)$ with an impact of 0.32 , namely, the relationship between the insertion into the network and global Innovation. In the discussion of results, we will discuss this association.

\section{EMBEDDEDNESS MODERATING EFFECT}

Completing the testing of hypotheses, we verified the moderating effect of the variable "embeddedness" through multiple-groups analysis. The results are shown in Table 6, both for the proposed associations, that is, H1a and H2c, as for those not proposed in the advocated hypotheses. The results show that subgroups (High Embeddedness and Low Embeddedness), in general, they do not present differences that may impact the model, except for moderation of the high embeddedness in the relationship between entrepreneurial orientation and local innovation (supporting H1a) where a significant difference was detected $(\mathrm{p}<0.01)$. In turn, H2c was not supported, which alleged that the moderating effect of the high embeddedness between local and global innovation.

Table 4. Hipothesis test (without moderation of the embeddedness)

\begin{tabular}{lccccccc}
\hline Hipothesis & \multicolumn{2}{c}{ Relationship between constructs } & $\lambda^{\mathrm{a}}$ & C.R $^{\mathrm{b}}$ & Sig. (p) & Results \\
\hline $\mathrm{H} 1 \mathrm{~b}$ & Global Innovation & $\leftarrow$ & Local Innovation & 0.15 & 2.44 & 0.01 & Aceita \\
$\mathrm{H} 2 \mathrm{~b}$ & Local Innovation & $\leftarrow$ & Insertion into the network & 0.31 & 2.03 & 0.04 & Aceita \\
$\mathrm{H} 2 \mathrm{a}$ & Insertion into the network & $\leftarrow$ & Entrepreneurship & 0.47 & 4.07 & 0.00 & Aceita \\
\hline
\end{tabular}

Note: (a) Standardized weights; (b) Critical Ratio. SOURCE: the authors

Table 5. Test of Non-proposed Associations (without the moderation of the embeddedness)

\begin{tabular}{lccccc}
\hline \multicolumn{2}{l}{ Relationship between the constructs } & $\lambda^{\mathrm{a}}$ & \multicolumn{2}{c}{$\mathrm{C}^{\mathrm{R}} \mathrm{R}^{\mathrm{b}}$} & Sig. (p) \\
\hline Inovação Global & $\leftarrow$ & Insertion into the network & 0.32 & 3.04 & 0.00 \\
Global Innovation & $\leftarrow$ & Entrepreneurship & 0.24 & 1.70 & 0.09 \\
Local Innovation & $\leftarrow$ & Entrepreneurship & 0.30 & 1.47 & 0.14 \\
\hline
\end{tabular}

Note: (a) Standardized weights; (b) Critical Ratio. SOURCE: the authors 
Table 6. Moderating Effect of Embeddedness: results of the multiple-groups analysis

\begin{tabular}{lccccccc}
\hline Hipotheses & \multicolumn{2}{c}{ Moderating Variable: Embeddedness } & High & Low & Z-score & Significance \\
\hline H1a & Local Innovation & $\leftarrow$ & Entrepreneurship & $1.04^{* *}$ & 0.26 & $2.69^{* *}$ & Yes \\
H2c & Inovação Global & $\leftarrow$ & Local Innovation & 0.12 & $0.27^{* *}$ & 1.20 & No \\
- & Global Innovation & $\leftarrow$ & Business networks & 0.23 & 0.15 & 0.36 & No \\
- & Local Innovation & $\leftarrow$ & Business networks & 0.10 & $0.57^{*}$ & 1.43 & No \\
- & Business networks & $\leftarrow$ & Entrepreneurship & $0.71^{* *}$ & 0.32 & 1.50 & No \\
- & Global Innovation & $\leftarrow$ & Entrepreneurship & 0.34 & 0.01 & 0.10 & No \\
\hline
\end{tabular}

**P $<0.01$ and $* \mathrm{P}<0.05$. Source: the authors

\section{MEDIATING EFFECT OF THE CONSTRUCTS: BUSINESS NETWORK AND LOCAL INNOVATION}

By following the criteria established by Hair Jr. et al. (2009), we found that the above results were bought when analyzed in Figure 2 the mediating effect of the constructs insertion into the network and local Innovation. In Figure 2 (III), we found that local innovation really does not exercise the mediating factor for global innovation when associated only with the entrepreneurial orientation without the moderation of Embeddedness. This result again conforms H1a, showing the importance of the moderation of the high embeddedness between the headquarters and subsidiary for the association between entrepreneurial orientation and local innovation.

In turn, we can verify in Figure 2 (I) that the insertion into the network, in fact, plays the mediating role between the entrepreneurial orientation and local innovation. The indexes are significant again supporting $\mathrm{H} 2 \mathrm{a}$ and $\mathrm{H} 2 \mathrm{~b}$. The insertion into the network is a mediating construct since it facilitates the relationship between the other two constructs involved (HAIR JR. et al., 2009). However, Figure 2 (II) draws attention to a proposal not advocated earlier in the article. The insertion into the network exerts mediating effect between the entrepreneurial orientation and global innovation, confirming the results previously reported in Table 5.

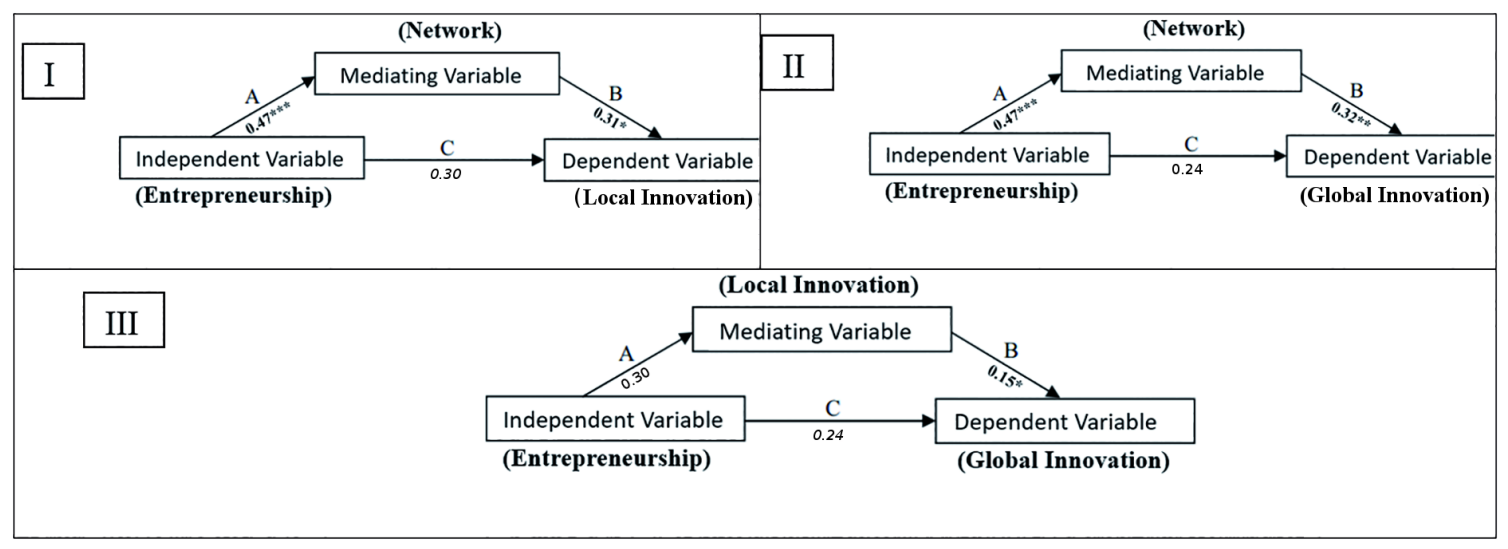

Figure 2. Mediating variable (Results)

\section{DISCUSSION OF RESULTS}

We began this discussion by presenting Figure 3 with the final model after the hypothesis tests. We advocate in the hypotheses two global innovation development processes. The first innovation process characterized by $\mathrm{H} 1 \mathrm{a}$ and $\mathrm{H} 1 \mathrm{~b}$ was supported by the hypothesis test. In turn, the second innovation process was not entirely supported by the absence of significance for the association established by H2c. Moreover, the results point to an 


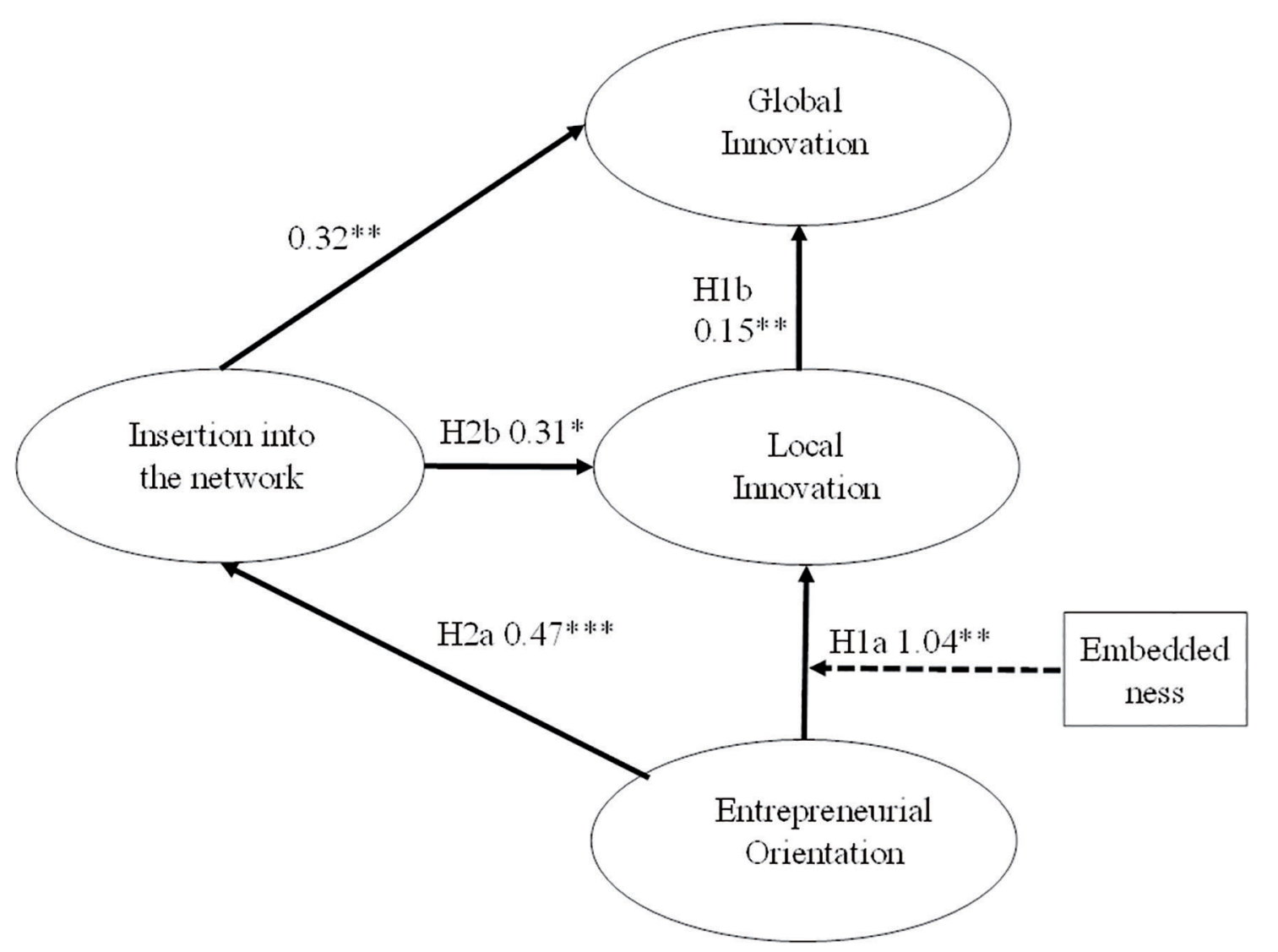

Figure 3. Summary of Results

association between insertion into the network and global innovation that we had not advocated.

The first global innovation development process was confirmed. We note that H1a: entrepreneurial orientation of the subsidiary, when moderated by embeddedness between headquarters and subsidiaries, is positively associated with local innovation and H1b: local subsidiary innovation is positively associated with global subsidiary innovation. This result reaffirms the proposition that, when the purpose of innovation is to meet the internal demand of the subsidiary (BIRKINSHAW, 1997), embeddedness has an important moderating role to align entrepreneurial orientation and local innovation with the corporate strategy patterns. This moderation is reaffirmed by the fact of the direct relationship not being significant between entrepreneurial orientation and local innovation. In fact, when we ask what is the role of embeddedness (YAMIN; ANDERSSON, 2011), it can be stated that embeddedness plays an important moderating role for global innovation oriented to the internal demands of the MNC.

The second global innovation development process has not been confirmed. Albeit we find that H2a: entrepreneurial orientation is positively associated with the insertion of the subsidiaries into the external network of the host country. H2b: the insertion of the subsidiaries into the external network of the host country is positively associated with local subsidiary of innovation; unfortunately, the last hypothesis of the model (H2c) was not confirmed. That is, it was not possible to say that local innovation of the subsidiary, when moderated by embeddedness between headquarters and subsidiaries, it is positively associated with global innovation of the subsidiary. In addition, in the support tests we did not verify the moderation of embeddedness in any other association. Thus, what can be said is that the entrepreneurial orientation is associated with the insertion into the network, 
BBR which in turn is important for the development of local innovations (ANDERSSON et al., 2002). This result is in line with the local-local paradigm (NOHRIA; GHOSHAL, 1997), which in this case is important for the competitiveness of the subsidiary in the host country, but without a global scale (RUGMAN; VERBEKE, 2001).

However, what draws attention is a result not advocated in the hypotheses of this article. This is the direct association between insertion into the network and global innovation, without the mediation of local innovation. This means that the insertion into the network is able to directly develop global innovations, i.e., innovations that are transferred to the headquarters directly without moderation of embeddedness. As we understand it, this happens when innovation created in the subsidiary is a radical innovation (UTTERBACK; ABERNATHY, 1975) or disruptive (CHRISTENSEN, 2013).

In particular, this radical or disruptive innovation draws attention to our sample in Brazil, an emerging market. Recent literature has emphasized the attention of the MNC for the reverse innovation possibilities (GOVINDARAJAN, 2012; GOVINDARAJAN;RAMAMURTI, 2011; GOVINDARAJAN; TRIMBLE, 2012), that would be derived from disruptive innovations created in emerging markets (IMMELT; GOVINDARAJAN; TRIMBLE, 2009) and with the possibility of creating new process and product paradigms for the $\mathrm{MNC}$, in particular by reducing the costs of products and processes and increasing margins (WILLIAMSON, 2010; ZENG; WILLIAMSON, 2007). As the MNC of a developed country does not hold the knowledge and expertise to develop this innovation alone (ZESCHKY; WIDENMAYER; GASSMANN, 2011, 2014; ZESCHKY; WINTERHALTER; GASSMANN, 2014), our result shows that, without doubt, the insertion into the network of the host country is essential for this kind of innovation.

\section{CONCLUSION}

Based on the network perspective and entrepreneurial orientation of subsidiaries, the article aims to show that embeddedness has a differentiated moderating role in two global innovation processes conceivable in MNCs. The results show that in fact, on a global innovation process that seeks to meet the internal demand of the MNC, moderation of embeddedness between entrepreneurial and local innovation is essential so that the latter becomes global innovation. This result is an important contribution to the literature that discusses the dual embeddedness (MEYER et al., 2011; NARULA, 2014) for showing that integration can play moderating role depending on the innovation process.

On the other hand, we did not confirm embeddedness as a moderator between local and global innovation resulting from a process stimulated by the entrepreneurial orientation and mediated by the insertion into the network. However, we found that the insertion into the network can directly lead to global innovation, since this innovation is disruptive or radical. Such a result, on the one hand shows that embeddedness is not always necessary for global Innovation (ANDERSSON et al., 2005; ANDERSSON et al., 2002). On the other, in our understanding, innovation resulting from this process must be a disruptive innovation, which can be very adherent to subsidiaries in emerging markets, given the advent of reverse innovation (GOVINDARAJAN; RAMAMURTI, 2011; GOVINDARAJAN; TRIMBLE, 2012). In this manner, future studies should explore in emerging markets, how the insertion into the network of the subsidiary can lead to the development of the reverse innovation.

\section{LIMITATIONS}

Studies in applied social sciences have instruments and theories capable of doing an approximation of reality, albeit incomplete and imperfect (MINAYO; DESLANDES, 2009), subject to avoidable and unavoidable errors. Avoidable mistakes are those related to theoretical and methodological limitations, while the inevitable errors relate to the limits of 
current scientific rationality (MINAYO et al., 2013). In this sense, it is worth recalling in this space some limitations of this research.

$\mathrm{Na}$ issue related to the applied questionnaire are the respondents (presidents, $\mathrm{CEO}$, vicepresidents, directors, and similar positions), which can bring a bias with respect to the lack of knowledge of all the issues addressed, despite the assumption that members of senior management know in a profound way the strategic activities developed by companies. One has to also take into account the quality of information, although these have been answered by members of senior management. In order to reduce the problem of bias, this research performed the Harman's factor analysis (PODSAKOFF; ORGAN, 1986).

Another evident limitation is the size of the sample, although suitable when compared to other studies and to the parameters suggested by Hair Jr et al. (2009). For this reason, other relationships could not be tested in this study. Furthermore, it is clear that use of stratified probability sampling would have increased the range of the results and therefore, the conclusions presented here. However, due to difficulties inherent in data collection, particularly from surveys, we used non-probability sampling for convenience in this study.

\section{REFERENCES}

ACHCAOUCAOU, F.; MIRAVITLLES, P.; LEÓN-DARDER, F. Knowledge sharing and subsidiary R\&D mandate development: A matter of dual embeddedness. International Business Review, 23(1), 76-90, 2014

ANDERSSON, U. Managing the transfer of capabilities within multinational corporations: the dual role of the subsidiary. Scandinavian Journal of Management, 19(4), 425-442, 2003.

ANDERSSON, U.; BJÖRKMAN, I.; FORSGREN, M. Managing subsidiary knowledge creation: The effect of control mechanisms on subsidiary local embeddedness. International Business Review, 14(5), 521-538, 2005.

ANDERSSON, U.; FORSGREN, M.; HOLM, U. The strategic impact of external networks: subsidiary performance and competence development in the multinational corporation. Strategic Management Journal, v.23, 2002.

ANDERSSON, U.; FORSGREN, M.; HOLM, U. Subsidiary embeddedness and competence development in MNCs a multi-level analysis. Organization Studies, v. 23, n. 22, p. 979996, 2001.

BARON, R.M.; KENNY, D.A. The Moderator-Mediator Variable Distinction in Social Psychological Research: Conceptual, Strategic, and Statistical Considerations. Journal of Personality and Social Psychology, v.51, n.6, 1986.

BARTLETT, C. A.; GHOSHAL, S. Managing Across Borders: The Transnational Solution. American Foreign Policy Interests: The Journal of the National Committee on American Foreign Policy, 21(3), 20-22, 1999.

BARTLETT, C. A.; GHOSHAL, S. Managing across borders: the transnational solution. Boston: Harvard Business School Press, 1989.

BARTLETT, C. A.; GHOSHAL, S. Tap your subsidiaries for global reach. Harvard Business Review, v. 64, n,6, p.87-94, 1986.

BIRKINSHAW, J. Strategy and Management in MNC subsidiaries. In A. Rugman \& T. L. Brewer (Eds.), The Oxford handbook of international business. USA: Oxford University Press, 2001.

BIRKINSHAW, J. Entrepreneuship in Multinational Corporations: The Caracteristics of Subsidiary Initiatives. Strategic Management Journal, 18: 207-229, 1997.

BIRKINSHAW, J.; HOOD, N. Multinational Corporate Evolution and Subsidiary Development. Macmillan Press Ltd, 1998.

BIRKINSHAW, J.; HOOD, N; JONSSON. Building firm-specific advantages in multinational corporations: The role of subsidiary initiative. Strategic Management Journal, v.19, n.3, p.221-242, 1998.

BIRKINSHAW, J.; HOOD, N.; YOUNG, S. Subsidiary entrepreneurship, internal and external competitive forces, and subsidiary performance. International Business Review, 14(2), 227248, 2005.

BIRKINSHAW, J.; RIDDERSTRÅLE, J. Fighting the corporate immune system: a process study of subsidiary initiatives in multinational corporations. International Business Review, 8(2), 149-180, 1999.

BOEHE, D. M. Captive offshoring of new product development in brazil: how does arbitrage influence local, collaborative relationships? Management International Review, 50(6), 747-773, 2010. 
BBR

14,4

BORINI, F. M.; FLEURY, M. T. L.; FLEURY, A. C.; OLIVEIRA JR, M. M. The relevance of subsidiaries initiatives for Brazilian multinationals. Revista de Administração de Empresas, 49(3), 253-265, 2009.

BORINI, F. M.; OLIVEIRA JUNIOR, M. M.; SILVEIRA, F. F.; CONCER, R. O. The Reverse Transfer of Innovation of Foreign Subsidiaries of Brazilian Multinationals. European Management Journal, 30(3), 219-231, 2012.

BOUQUET, C.; BIRKINSHAW, J. Weight versus voice: How foreign subsidiaries gain attention from corporate headquarters. Academy of Management Journal, 51(3), 577-601, 2008.

BYRNE, B. M. Structural equation modeling with AMOS: basic concepts,applications, and programming. 2nd edition. New York: Taylor \& Francis Group, 2009.

CANTWELL, J.; MUDAMBI, R. MNE competence-creating subsidiary mandates. Strategic Management Journal, 26(12), 1109-1128, 2005.

CHANG, M-L.; CHENG, C-F.; WU, W-Y. How Buyer-Seller Relationship Quality Influences Adaptation and Innovation by Foreign MNCs' Subsidiaries. Industrial Marketing Management, 41 (7), 2012.

CHANG, S.-J.; VAN WITTELOOSTUIJN, A.; EDEN, L. From the editors: Common method variance in international business research. Journal of International Business Studies, 41(2), 178-184, 2010.

CHAN, F. T. S.; CHONG, A. Y. L. A SEM-neural network approach for understanding determinants of interorganizational system standard adoption and performances. Decision Support Systems, 54(1), 621630. 2012.

CHESBROUGH, H. Open innovation: The new imperative for creating and profiting from technology: Harvard Business Press, 2006.

CHRISTENSEN, C. The innovator's dilemma: when new technologies cause great firms to fail: Harvard Business Review Press, 2013.

CIABUSCHI, F.; DELLESTRAND, H.; HOLM, U. The role of headquarters in the contemporary MNC. Journal of International Management, 18(3), 213-223, 2012.

CIABUSCHI, F.; HOLM, U.; MARTÍN MARTÍN, O.Dual embeddedness, influence and performance of innovating subsidiaries in the multinational corporation. International Business Review, 23(5), 897-909, 2014.

COSTA, S.; BORINI, F. M.; AMATUCCI, M. Global innovation in foreign subsidiaries located in emerging markets. Revista de Administração Contemporânea, 17(4), 459-478, 2013.

DELANY, E. Strategic development of the multinational subsidiary through subsidiary initiative-taking. Long Range Planning, 33(2), 220-244, 2000.

D' AgOstino, L. M.; SANTANGELO, G. D.Do Overseas R\&D Laboratories in Emerging Markets Contribute to Home Knowledge Creation? Management International Review, 52(2): 251 -273, 2012.

DELLESTRAND, H. (2011). Subsidiary embeddedness as a determinant of divisional headquartersinvolvement in innovation transfer processes. Journal of International Management, v. 17, n. 3, p. 229-242, 2011.

DESLANDES, Suely Ferreira. Introdução à metodologia científica da pesquisa. Curso deEAD: Fiocruz, 2004. Disponível em:<http://www.extranet.ead.fiocruz.br/criacao/qssp/QSSP-PercursoAprendizagem/ texto_deslandes.pdf $>$. Acesso em: 31 julho 2015.

DIMITRATOS, P.; LIOUKA, I.; ROSS, D.; YOUNG, S. The multinational enterprise and subsidiary evolution: Scotland since 1945. Business History, 51(3), 401-425, 2009.

DIMITRATOS, P.; LIOUKA, I.; YOUNG, S. A missing operationalization: entrepreneurial competencies in multinational enterprise subsidiaries. Long Range Planning, 47(1-2),pp. 64-75, 2014.

DOZ,Y.; SANTOS, J.; WILLIAMSON, P. From global to metanational: How companies win in the knowledge economy. Harvard Business School Press, 2001.

DYER, J. H.; NOBEOKA, K.Creating and managing a high-performance knowledge-sharing network: The Toyota case. Strategic Management Journal, v. 21, p. 345-367, 2000.

EYRING, M.; JONSSON, M.; NAIR, N. New business model in emerging markets. Harvard Business Review, 89(1), 88-95, 2011.

FIGUEIREDO, P. N. The role of dual embeddedness in the innovative performance of MNE subsidiaries: evidence from Brazil. Journal of Management Studies, 48(2), 417-440, 2011.

FIGUEIREDO, P. N.;BRITO, K.The innovation performance of MNE subsidiaries and local embeddedness: evidence from an emerging economy. Journal of Evolutionary Economics, 21(1), 141-165, 2011.

FORNELL, C.; LARCKER, D. F. Evaluating structural equation models with unobservable variables and measurement error: algebra and statistics. Journal of Marketing, v. 18, n. 1, p. 39-59, Feb. 1981.

FORSGREN, M. Theories of the Multinational Firm: A Multidimensional Creature in the Global Economy. USA: Edward Elgar Publishing, Inc, 2008. 
FORSGREN, M.; HOLM, Ulf; JOHANSON, J. Managing the embedded multinational: a business network view. Cheltenham: Edward Elgar, 2005.

FOSS, N.; LAURSEN, K.; PEDERSEN, T. Linking customer interaction and innovation: the mediating role of new organizational practices, Organization Science, Vol. 22, pp.980-999, 2011.

FROST, T.; BIRKINSHAW, J.; ENSIGN, P.Centers of excellence in multinational corporations. Strategic Management Journal, 23(11), 997-1018, 2002.

GOLDMAN SACHS. BRIC Monthly. Global Economics, New York, n.10/03, May 20, 2010.

GNYAWALI, D. R.; HATFIELD, D. E. Foreign subsidiaries' learning from local environments: An empirical test. Management International Review, 47(1), 79-102, 2007.

GOVINDARAJAN, V. A Reverse-Innovation Playbook: Insights from a company that developed products for emerging markets and then brought them back home. Harvard Business Review, 2012.

GOVINDARAJAN, V.; TRIMBLE, C. Reverse innovation. Boston: Harvard Business Press, 2012.

GOVINDARAJAN, V.; RAMAMURTI, R. Reverse innovation, emerging markets, and global strategy. Global Strategy Journal, v. 1, p. 191-205, 2011.

GUPTA, A.; GOVINDARAJAN, V. Knowledge Flows within Multinational Corporation. Strategic Management Journal, v. 21, n. 4, p. 473-496, 2000.

HAIR J. F.; BLACK, W. C.; BABIN, B. J.; ANDERSON, R. E.; TATHAM, R. L. Análise Multivariada de dados. Trad. Adonai Schlup Sant"Anna. 6ed. Porto Alegre: Bookman, 2009.

HAKANSON, L.; NOBEL, R. Technology characteristics and reverse technology transfer. Management International Review, 40(1), 29-48, 2000.

HAMEL, G.; BREEN, B. The future of management, Harvard: Business School Press, 2007.

HEIDENREICH, M.; BARMEYER, C.; KOSCHATZKY, K.; MATTES, J.; BAIER, E.; KRUTH, K. Multinational Enterprises and Innovation: Regional Learning in Networks. New York: Routledge, 2012.

HENSELER, J.; FASSOTT, G. Testing Moderating Effects in PLS Path Models: An Illustration of Available Procedures. (V. Esposito Vinzi, W. W. Chin, J. Henseler, \& H. Wang, Eds.) Handbook of Partial Least Squares, p. 713-735, 2010.

HOOPER, D.; COUGHLAN, J.; MULLEN, M. Structural Equation Modeling: Guidelines for Determining Model Fit, Electronic Journal of Business Research Methods, 6(1), 2009.

HYMER, S. The International Operations of National Firms: A Study of Direct Investment. Cambridge, MA: MIT Press (reprint of PhD dissertation, MIT, 1960), 1976.

IMMELT, J. R.; GOVINDARAJAN, V.; TRIMBLE, C. How GE is disrupting itself. Harvard Business Review, October, 56-65, 2009.

JARVIS, C. B.; MACKENZIE, S.; PODSAKOFF, P. A critical review of construct indicators and measurement model misspecification in marketing and consumer research. Journal of Consumer Research, 30(2), 199218, 2003.

KALE, P.; SINGH, H.; PERLMUTTER, H. Learning and protection of property assets in strategic alliances: building relational capital. Strategic Management Journal, 2000.

KEUPP, M. M.;GASSMANN, O. International innovation and strategic initiatives: A research agenda. Research in International Business and Finance, 23(2), 193-205, 2009.

KLINE, Rex B. Principles and practice of structural equation modeling. 2nd edition. New York: The Guilford Press, 2005.

LAKSHMAN, C., PARENTE, R.C. Supplier-Focused Knowledge Management in the Automobile Industry and Its Implications for Product Performace. Journal of Management Studies, 2008.

LI, Y.; WANG, X.; HUANG, L.; BAI, X.How does entrepreneurs' social capital hinder new business development? A relational embeddedness perspective. Journal of Business Research, 2013.

LI, Chia-Ying. Knowledge stickiness in the buyer-supplier knowledge transfer process: The moderating effects of learning capability and social embeddedness. Expert Systems with Applications, v. 39, n 5, p. 5396-5408, 2012.

MARKIDES, C. C. How Disruptive Will Innovations from Emerging Markets Be? Mit Sloan Management Review, 54(1), 23-25, 2012.

MAROCO, João. Análise Estatística com o PASW Statistics (ex-SPSS). $1^{\text {a }}$ Ed. Portugal, Lisboa: Editora ReportNumber, 2010.

MCGUINESS M.; DEMIRBAG M.; BANDARA S. Towards a Multi-perspective Model of Reverse Knowledge Transfer in Multinational Enterprises: A Case Study of Coats plc. European Management Journal, Vol. 31, No. 2, pp. 179-195, 2013. 
BBR

14,4
MEYER, K., MUDAMBI, R., \& NARULA, R. Multinational Enterprises and Local Contexts: The Opportunities and Challenges of Multiple Embeddedness. Journal of Management Studies, 48(2), 235$252,2011$.

MICHAILOVA, S.; MUSTAFFA, Z. Subsidiary knowledge flows in multinational corporations: Research accomplishments, gaps, and opportunities. Journal of World Business, v. 47, n. 3, p. 383-396, 2012.

MINAYO, M. C. S.; DESLANDES, S. F. Pesquisa social: teoria, método e criatividade. 28. ed. Petrópolis, RJ: Vozes, 2009.

MINBAEVA, D. HRM Practices affecting extrinsic and intrinsic motivation of knowledge receivers and their effect on intra-MNC knowledge transfer. International Business Review, 17(6), 703-713, 2008.

MINBAEVA, D. B. Knowledge Transfer in Multinational Corporations. Management International Review, v. 47, p. 567-593, 2007.

MU, S.; GNYAWALI, D. R.; HATFIELD, D. E. (2007). Foreign Subsidiaries' Learning from Local Environments: An Empirical Test. Management International Review, 47, 1: 79-102, 2007.

MUDAMBI, R.; PEDERSEN, T.; ANDERSSON, U. How subsidiaries gain power in multinational corporations. Journal of World Business, 49(1), 101-113, 2014.

MULAIK, S. A.; JAMES, L. R.; VAN ALSTINE, J.; BENNETT, N.; LIND, S.; STILWELL, C. D. Evaluation of goodness-of-fit indices for structural equation models. Psychological Bulletin, 105(3), 430, 1989.

NARULA, R. Exploring the Paradox of Competence-creating Subsidiaries: Balancing Bandwidth and Dispersion in MNEs. Long Range Planning, 47(1-2), 4-15, 2014.

NELL, P. C.; AMBOS, B.; SCHLEGELMILCH, B. B. The MNC as an externally embedded organization: An investigation of embeddedness overlap in local subsidiary networks. Journal of World Business, 46(4), 497-505, 2011.

NOHRIA, N.; GHOSHAL, S. The Differentiated Network: Organizing Multinational Corporations for Value Creation. San Francisco: Jossey-Bass Publishers, 1997.

OLIVEIRA JR, M.; BOEHE, D. M.; BORINI, F. M. Estratégia e inovação em corporações multinacionais: a transformação das subsidiárias brasileiras. São Paulo: Saraiva, 2009.

PODSAKOFF, P. M.; ORGAN, D. W.Self-reports in organizational research: problems and prospects. Journal of Management, 12(4), 531-544, 1986.

REILLY, M.; SCOTT, P. Subsidiary driven innovation within shifting MNC structures: Identifying new challenges and research directions. Technovation, 34(3), 190-202, 2014.

RIGDON, E. E.; SCHUMACKER, R. E.; WOTHKE, W. A comparative review of interaction and nonlinear modeling. In: R. E. Schumacker; George A Marcoulides (Eds.); Interaction and Nonlinear Effects in Structural Equation Modeling. p.1-16, 1998.

RUGMAN, A.; VERBEKE, A.; YUAN, W.Re-conceptualizing Bartlett and Ghoshal's Classification of National Subsidiary Roles in the Multinational Enterprise. Journal of Management Studies, 48(2), 253$277,2011$.

RUGMAN A.; VERBEKE, A. subsidiary specific advantages in multinational enterprises. Strategic Management Journal, 22(3), 237-250, 2001.

SANTANGELO, G. D. The tension of information sharing: Effects subsidiary embeddedness. International Business Review. v. 21, n. 2, p. 117-310, 2012.

SAUER, Paul L.; DICK, Alan. Using moderator variables in structural equation models. In:ADVANCES IN CONSUMER RESEARCH, 1993. Proceedings. Provo, UT: Associationfor Consumer Research, v.20, p.636-640, 1993.

SCHMID, S.; DZEDEK, L. R.; LEHRER, M. From Rocking the Boat to Wagging the Dog: A Literature Review of Subsidiary Initiative Research and Integrative Framework. Journal of International Management, 20(2), 201-218, 2014.

SCOTT, P.; GIBBONS, P.; COUGHLAN, J. Developing subsidiary contribution to the MNC-Subsidiary entrepreneurship and strategy creativity. Journal of International Management, 16(4), 328-339, 2010.

TANG, F.; MU, J.; MACLACHLAN, D. L.Implication of network size and structure on organizations' knowledge transfer. Expert Systems with Applications, v. 34, p. 1109-1114, 2008.

TIDD, J.; BESSANT, J. Gestão da inovação, 5 ed.: Bookman Editora, 2015

UTTERBACK, J. M.; ABERNATHY, W. J. A dynamic model of process and product innovation. Omega, 3(6), 639-656, 1975.

UZZI, B.; Lancaster, R.Relational embeddedness and learning: The case of bank loan managers and their clients. Management Science, v. 49, p. 383-399, 2003.

WILLIAMS, C. Subsidiary-level determinants of global initiatives in multinational corporations. Journal of International Management, 15(1), 92-104, 2009. 
YAMIN, M.; ANDERSSON, U. Subsidiary importance in the MNC: What role does internal embeddedness play? International Business Review, 20(2), 151-162, 2011.

YANG, Q.; MUDAMBI, R.; MEYER, K. Conventional and Reverse Knowledge Flows in Multinational BBR Corporations. Journal of Management, 34(5), 882-902, 2008.

YOUNG, S.; TAVARES, A. T. Centralization and autonomy: back to the future. International Business Review, Vol. 13 No. 2, pp. 215-37, 2004.

YOUNG, S.; DIMITRATOS, P.; DANA, L-P. International entrepreneurship research: what scope for International Business Theories? Journal of International Entrepreneurship, v. 1, n. 1, p. 31-42, 2003.

ZENG, M.; WILLIAMSON, P. Dragons at your door: How Chinese cost innovation is disrupting global competition. Boston, MA: Harvard Business School Press, 2007.

ZESCHKY, M.; WIDENMAYER, B.; GASSmann, O. Frugal innovation in emerging markets. ResearchTechnology Management, 54(4), 38-45, 2011.

ZESCHKY, M.; WIDENMAYER, B.; GASSMANN, O. Organising for reverse innovation in Western MNCs: the role of frugal product innovation capabilities. International Journal of Technology Management, 64(24), 255-275, 2014.

ZESCHKY, M. B.; WINTERHALTER, S.; GASSMANN, O. From cost to frugal and reverse innovation: mapping the field and implications for global competitiveness. Research-Technology Management, 57(4), 20-27, 2014. 